\title{
Anti-Fibrotic Effects by Moringa Root Extract in Rat Kidney Fibroblast
}

\author{
Su-Hyun Park ${ }^{1,2}$ and Young-Chae Chang ${ }^{1,2}{ }_{\star}$ \\ ${ }^{1}$ Research Institute of Biomedical Engineering and ${ }^{2}$ Department of Medicine, Catholic University of Daegu School of Medicine, Daegu 705-718, \\ Korea
}

Received August 13, 2012 /Revised September 16, 2012 /Accepted October 5, 2012

\begin{abstract}
Fibrosis in kidney by internal and external factors causes progressive loss of renal function. Renal fibrosis is the inevitable consequence of an excessive accumulation of the extracellular matrix. TGF- $\beta$ plays an important role in the process of renal fibrosis and stimulates the synthesis of profibrotic factors, including collagens, fibronectin, and plasminogen activator inhibitor (PAI-1). We examined the effect of Moringa oleifera Lam (moringa) extracts in a rat kidney fibrosis model. We found that moringa root extract suppresses protein expression/mRNA levels of Type I collagen, fibronectin, and PAI-1 induced by TGF- $\beta$ in renal fibroblasts. Moringa root extract selectively inhibited phosphorylation of TGF- $\beta$-induced T $\beta R I I$ and the downstream signaling pathway (e.g., Smad4), and phospho-ERK, but not JNK, p38, or PI3K/AKT. These results suggest that moringa root extract can act against TGF- $\beta$ -induced renal fibrosis in rat kidney fibroblast cells by a mechanism related to its antifibrotic activity, which regulates expression of fibronectin, Type I collagen, and PAI-1 through TßRII - Smad2/3 Smad4 and ERK. Therefore, moringa root extract is an effective substance for fibrosis therapy and provides a new therapeutic strategy for diseases associated with elevated profibrotic factor synthesis.
\end{abstract}

Key words : Fibrosis, moringa, PAI-1, Type I collagen, fibronectin

\section{서 론}

섬유화는 우리 몸의 장기 조직이 외부적 또는 내부적 자극 을 받은 경우 조직에 염증이 생기고 손상되어 두꺼워지는 병 리학적 현상으로 심장, 폐, 간, 신장을 포함한 대부분 장기에 발생될 수 있으며[6], 다양한 사이토카인에 의한 섬유아세포의 활성화, 염증반응에 기인한 단핵세포와 대식세포 침투에 의한 조직손상 및 세포자살 등으로부터 유도된다[24]. 섬유화를 유 도하는 대표적 인자로는 IL-1 (interleukin-1), TGF- $\beta$ (transforming growth factor- $\beta$ ), TNF-a (tumor necrosis factor-a) 등이 있으며, 이 중 TGF- $\beta$ 는 다기능적 사이토카인으로 세포증식 및 분화, 세포자살에 작용하고, 세포 외 기질 단백질 분해를 억제하는 PAI-1 (plasminogen activator inhibitor-1) 활성과 fibronectin, Type I collagen과 같은 세포 외 기질 단백 질 축적을 증가 시켜 섬유화 유도에 핵심인자로 작용한다 $[12,22]$.

TGF는 작용수용체인 TGF- $\beta$ type I receptor (T $\beta R I)$ 와 TGF$\beta$ type II receptor (TßRII)와 결합하여 serine/threonine kinase를 활성화 시키고[15], 하위기전인 Smad의 인산화를 유도 한다[2]. TGF- $\beta$ 신호기전에 의해 활성화 되는 Smad는 r-Smad (receptor-regulated Smads), i-Smad (inhibitory Smads), co-Smad (common-mediator Smad)로 나누어지며, r-Smads

*Corresponding author

Tel : +82-53-650-4848, Fax : +82-53-650-4849

E-mail : ycchang@cu.ac.kr
(Smads 1, -2, -3, -5, -8,-9)는 TBRI에 의해 직접적으로 인산화 되어 상호작용하는 co-Smad인 Smad4와 결합, 핵으로 이동하 여 섬유화 유도 기전을 활성화 시킨다[2,22,35]. i-Smad (Smad-6,7)는 TßRI과 상호작용하여 r-Smad와 co-Smad의 활 성을 저해시켜 TGF- $\beta$ 신호전달 기전을 억제-조절한다고 알려 져 있다[14,18,23,31,37]. TGF- $\beta$ 신호 기전은 Smad 기전뿐만 아니라 MEK/ERK와 phosphoinositide 3-kinase (PI3K)를 활 성화 시키며[2,7], 최근 연구 결과에서는 TGF- $\beta$ 에 의해 활성화 된 $\mathrm{TAK} 1$ 이 하위의 $\mathrm{JNK}$ 와 $\mathrm{p} 38, \mathrm{NF}-\mathrm{kB}$ 를 활성화시켜 신장섬유 화를 조절한다는 연구결과도 발표된 바 있다[27].

앞에서 언급한 바와 같이 TGF- $\beta$ 로 유도되는 인자인 PAI-1 은 특이적으로 신장에서는 발현되지 않으나 섬유화 진행 시 과발현 되어 급성 또는 만성적인 신장질환을 유도하고 TGF- $\beta$ 를 비롯한 IL-1, TNF- $a$ 와 같은 염증관련 사이토카인에 의해 활성화 된다 $[9,29,33,40]$. TGF- $\beta$ 로 활성화 되는 PAI- 1 은 대표 적으로 $\mathrm{EGFR/pp60c-src/MEK/ERK} \mathrm{기전을} \mathrm{통해} \mathrm{조절되며}$ [21], Rho/ROCK에 의존적인 $\mathrm{Smad} 2$ 작용을 통해 유도된다 [7,34]. 그러나 TGF- $\beta$ 의 다기능적인 작용으로 최근에도 TGF- $\beta$ 와 PAI-1과의 발현조절기전 연구가 계속되고 있다. 또한 정상 조직에서 세포골격을 구성하고 세포 migration을 통해 상처 치료에 중요한 역할을 하는 fibronectin은 과발현시 조직경화 를 유발하며 $[5,17,20]$ 상피세포에서 TGF- $\beta$ 에 의해 JNK와 $\mathrm{ERK} 1 / 2$ 에 의존적으로, $\mathrm{Smad}$ 신호기전에 비의존적으로 조절 되어 섬유아세포의 분화를 유도한다[16,19]. Type I collagen은 세포 외 기질의 중요한 구성요소로서 fibronectin과 같이 세포 
외 기질에서 과다축적이나 과다합성 될 경우 섬유화를 포함한 다양한 질병을 유발한다[39]. 폐 섬유화 모델에서 Type I collagen은 MAPK 신호기전에 의존적으로 유도되며[32], IL-4와 IL-13으로 유도되는 피부 섬유화에서는 ERK를 통하여 조절된 다고 알려져 있다[4].

Moringa oleifera Lam은 moringaceae의 한 종류로 높이가 5-10 m에 이르는 나무이다[1]. 모링가는 아시아, 아프리카, 아 라비아 등에서 재배되며 단백질과 비타민이 풍부해 영양가가 높고, 의약적으로 과혈당증과 항염증, 항암 등 다양한 약리작 용을 가지고 있다 $[1,3,11,28]$. 모링가의 다양한 부위들 중 음식 으로 주로 이용되는 모링가 잎은 $\beta$-카로틴, 단백질, 비타민 $\mathrm{C}$, 칼슘 등이 풍부해 항산화제로 이용되며[36], 모링가 씨 추출 물은 flavonoid와 isothiocyanates, glucosinolates, thiocarbamates와 같은 생리활성물질을 포함하고 있다[11]. 또한 모링가 씨 추출물이 간 기능 보호에 효과가 있는 것으로 확인 되었으며[13], 암세포의 세포자살과 항증식 효과가 있다는 것 이 밝혀진 바 있다[38]. 그러나 모링가의 이러한 효과들에 대한 정확한 기전이 규명되어 있지 않다.

따라서 본 연구에서는 신장섬유화를 연구모델로 하여 모링 가 추출물들을 신장섬유화 유도 세포에 처리하여 PAI-1과 Type I collagen, fibronectin의 발현확인을 통해 모링가 추출 물의 항섬유화 효과를 확인하였으며, 이들 발현에 대한 모링 가 추출물의 조절 기전을 연구하였다.

\section{재료 및 방법}

\section{모링가 추출물 제조 및 세포배양}

신장 섬유아 세포주(rat kidney fibroblast cell, NRK-49F)는 American type culture collection으로부터 구입하였다. 신장 섬유아세포는 10\% 혈청(fetal bovine serum,FBS) (Gibco-BRL, Grand Island, NY)과 $1 \%$ 항생제(Gibco)를 함유한 DMEMlow glucose (Dulbecco's modified Eagle's medium)(Gibco) 배지에서 $37^{\circ} \mathrm{C}, 5 \% \mathrm{CO}_{2}$ 조건 하에 배양하였다. TGF- $\beta, \mathrm{PAI}-1$, Type I collagen, Smad4, p-ERK, p-JNK, p-p38, p-AKT, p-PI3K, $\beta$-actin은 Santa Cruz biotechnology (Santa Cruz, $\mathrm{USA}$ )에서 구입하여 사용하였다. 본 실험에 사용한 모링가는 스리랑카에서 구입하여 부위별로 분말화 된 시료를 주식회사 유림물산(대구시 달서구 월암동 1-83)에서 제공받아 사용하였 다. 시료 무게의 10 배 $(\mathrm{w} / \mathrm{v})$ 의 $80 \%$ 메탄올에 가하여 24 시간 동안 정치하여 총 3 회 반복 추출하였다. 추출액을 여과하여 rotary vacuum evaporator (R-3000, Büchì Switzerland)로 $55^{\circ} \mathrm{C}$ 에서 농축한 다음 건조하여 사용하였다.

WST-1 assay

6 시간과 12 시간 동안 모링가 추출물을 처리한 신장 섬유아 세포에 WST-1 reagent를 4 시간 동안 처리한 후 분광광도계를
이용하여 세포 증식 수치를 측정하였다.

\section{Western blot analysis}

신장 섬유아세포를 $3 \times 10^{5} / 100 \mathrm{~mm}$ dish에 배양배지로 85-90\% 정도의 밀도가 되도록 배양하였다. 기존의 배양액을 제거하고, 무혈청 배양액에 모링가 추출물 처리 30 분 전 유도 물질인 TGF- $\beta 2 \mathrm{ng} / \mathrm{ml}$ 을 처리하여 모링가 추출물과 함께 6 시간 동안 배양하였다. 배양 후 배양액을 제거하고 세포를 스 크래퍼로 긁어 모아 $4^{\circ} \mathrm{C}, 12,000 \mathrm{rpm}$ 으로 10 분 간 원심분리하 여 상등액을 제거하고 IPH lysis buffer $(50 \mathrm{mM} \mathrm{pH}$ 8.0, Tris $150 \mathrm{mM} \mathrm{NaCl}, 5 \mathrm{mM}$ EDTA, 0.5\% NP40, $100 \mathrm{mM}$ PMSF, leupeptin $1 \mathrm{mg} / \mathrm{ml}$, aprotinin $1 \mathrm{mg} / \mathrm{ml}$, and $1 \mathrm{M} \mathrm{DTT}$ )로 현탁 시켰다. $4^{\circ} \mathrm{C}$ 에서 20 분 동안 현탁 시키고 $12000 \mathrm{RPM}$ 에서 20 분 동안 원심분리한 후, 세포 추출물로부터 단백질을 분리 하였다. 추출한 단백질은 정량하여 DTT가 첨가된 $2 \times S \mathrm{SDS}$ loading buffer (100 mM pH 6.8 Tris-Cl, glycerol 20\%, bromophenol blue $0.2 \%$, SDS $4 \%$, dithiothreitol $200 \mathrm{mM}$ )와 섞어 $98^{\circ} \mathrm{C}$ 에서 5 분간 열을 가한 후 $10 \%$ SDS-PAGE gel에 전기 영동하여 Immobilon-P-membrane (Whatman, Germany)에 이동시켰다. Membrane은 일차항체 anti-p-TßRII, anti-Smad4, anti-p-ERK, anti-p-p38, anti-p-AKT, anti-p-PI3K, anti-p-JNK 와 반응시키고 이차항체와 각각 반응시켰다. 항체들에 대한 발현분석은 Horseradish Peroxidase-Linked 이차항체에 의해 발현되는 ECL Western Blot Analysis 시스템을 이용하여 결과 를 분석하였다.

Reverse Transcriptase Polymerase chain reaction
(RT-PCR)

RNA 분리는 Trizol reagent (Invitrogen, Carlsbad, CA)를 이용하였으며 $1 \mu \mathrm{g}$ 의 RNA를 사용하여 Moloney murin leukemia virus reverse transcriptase (Promega, Meadison, WI)로 역전사 반응을 시켜 $\mathrm{cDNA}$ 를 합성하였다. 합성된 $\mathrm{cDNA}$ 를 이 용하여 PAI-1과 Type I collagen, fibronectin의 primer를 이용 하여 PCR을 수행하였고, 생성된 결과물은 $1 \%$ agarose gel로 전기 영동하여 ethidium bromide와 결합시켜 가시화하여 결 과를 확인하였다. PCR을 위한 primer 염기서열은 다음과 같 다. PAI-1: forward 5'-TGTCCTCGGTGCTGGCTATGCTG-3' and reverse 5'-TCAGACTTGTGGAACAGGCGCTG-3'; fibronectin: forward 5'- GCATCAGGGCAGGGAAAGCAA-3' and reverse 5'-GTTGGTTGGGGGAGACAGCGG-3'; Type I collagen: forward $5^{\prime}$-TGGGGCAAGACAGTCATCGAATAC A- $3^{\prime}$ ) and reverse 5'-GGCAGCATTTGGGGTATCATAAG-3'. $\beta$-actin forward $5^{\prime}$-AGGGTGTGATGGGTATGGG-3' and reverse 5'-CAGGATCTTCATGAGGTAGTC-3'

\section{통계적 분석}

모든 실험결과에 대한 통계처리는 각 실험 군별로 표준차이 
가 있는가를 검증하기 위해 분산분석을 수행하였으며 다양성 분석은 Duncan's test로 분석하였다. 통계처리 후 $\mathrm{p}$ 값이 0.05 미만일 경우( $\beta \times 0.05)$ 통계적인 유의성이 있다고 판정하였다.

\section{결 과}

\section{신장 섬유아세포 증식에 대한 모링가 추출물의 작용}

신장 섬유아세포를 $1 \times 10^{4} / \mathrm{ml}$ 로 96 wells에서 1 일 동안 배 양한 후, 모링가 뿌리, 씨, 열매, 잎 추출물을 각각 $50,100,200$, $400 \mathrm{\mu g} / \mathrm{ml}$ 로 6 시간과 12 시간 동안 처리한 뒤 WST-1 reagent 를 4 시간 동안 반응시켜 모링가 추출물이 세포증식에 미치는 영향을 확인하였다.

실험 결과 무처리구와 비교하였을 때, 6 시간과 12 시간 모 두 뿌리와 씨 추출물에 대한 세포 증식은 큰 영향이 없었으나, 열매와 잎을 처리한 경우 농도 의존적으로 $60 \%$ 미만으로 세포 증식을 감소시키는 것으로 확인되었다(Fig. 1). 결과적으로 이 후 실험에서의 약물 처리 농도는 신장 섬유아세포 증식에 영 향이 없는 $100 \mu \mathrm{g} / \mathrm{ml}$ 이하 범위에서 진행하였다.

A

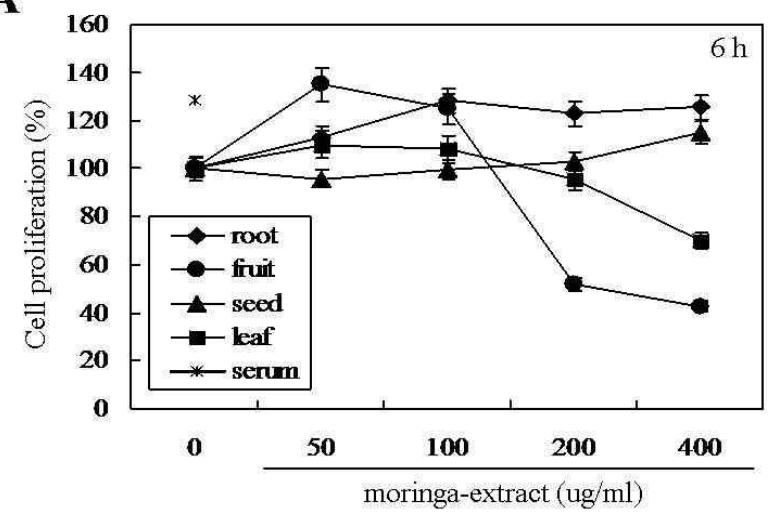

B

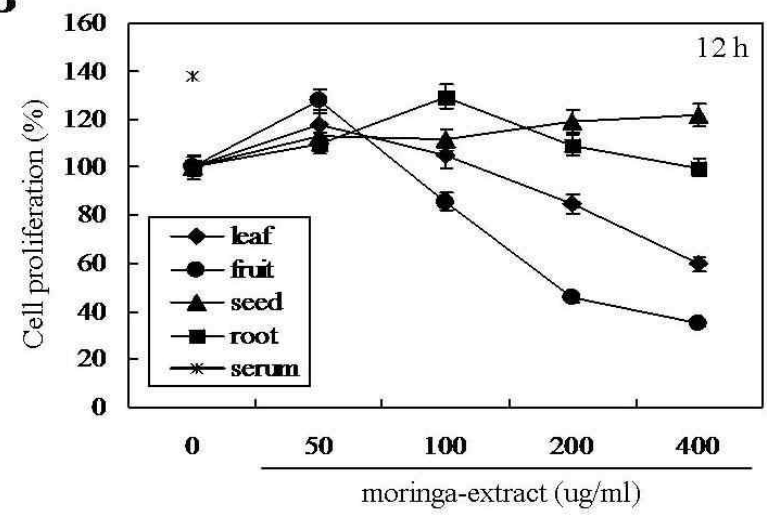

Fig. 1. Effect of moringa on the proliferation of the rat kidney fibroblasts. Rat kidney fibroblast cells $\left(1 \times 10^{4}\right.$ cells $\left./ \mathrm{ml}\right)$ were treated with various moringa extracts in the absence of serum for $6 \mathrm{hr}(\mathrm{A})$ and $12 \mathrm{hr}$ (B). Cell proliferation was determined by WST-1 assay. Results shown are means \pm SE of three separate experiments.
모링가 추출물에 의한 섬유화 관련 인자의 발현 저해 효과

TGF- $\beta$ 에 의한 신장 섬유아세포의 섬유화 유도 유무와 모링 가 추출물에 의한 섬유화 억제 효과를 확인하고자 섬유화 유 도 유전자인 PAI-1과 Type I collagen의 단백질과 mRNA 발 현 정도를 확인하였다.

TGF- $\beta$ 에 의해 증가된 PAI-1과 Type I collagen의 단백질 발현이 모링가 씨와 뿌리추출물에 의해 감소되었다(Fig. 2A). 그러나 전사단계에서의 PAI-1과 Type I collagen mRNA 발 현에 대한 모링가 추출물의 영향을 확인한 실험에서 TGF- $\beta$ 에 의해 증가된 PAI-1과 Type I collagen의 mRNA 발현이 모링가 뿌리추출물에 의해서만 감소 되었다(Fig. 2B). 따라서 섬유화 유도인자들의 단백질 및 $\mathrm{mRNA}$ 발현 감소가 모링가 씨와 뿌리추출물 처리에 의한 것임을 예상할 수 있다. 그리 고 PAI-1, Type I collagen의 mRNA발현은 모링가 뿌리추출 물에 의해서만 감소되어 이후 실험은 섬유화 유도 인자 발현 에 가장 영향이 있는 모링가 뿌리추출물을 이용하여 진행하 였다.

A

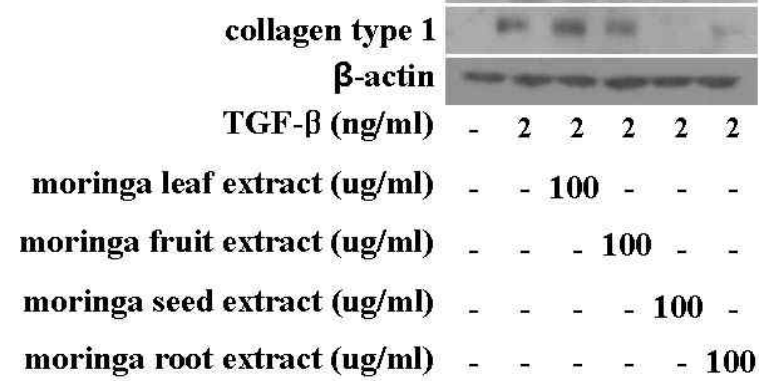$$
\text { A }
$$

B

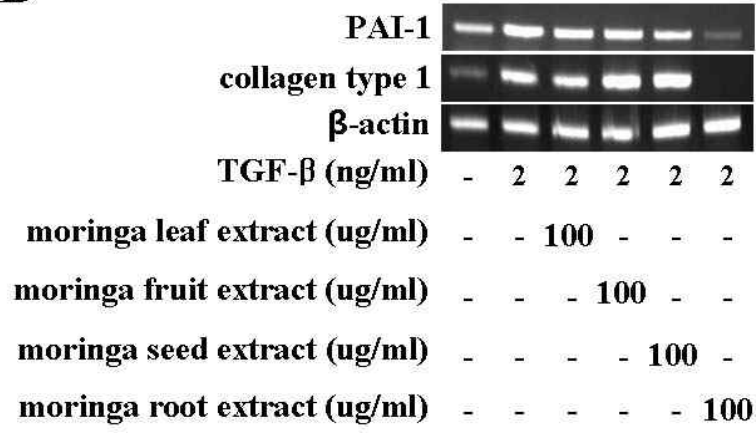

Fig. 2. Regulation of profibrotic gene expression by various moringa extracts. Rat kidney fibroblast cells $\left(3 \times 10^{5} / 100 \mathrm{~mm}\right)$ were incubated with $2 \mathrm{ng} / \mathrm{ml}$ TGF- $\beta$ for $30 \mathrm{~min}$, followed by treatment with various moringa extracts for $6 \mathrm{hr}$. The protein expression (A) and mRNA expression (B) were analyzed by western blot and RT-PCR. $\beta$-actin expression was included as an internal control. A representative of three independent experiments in shown. 
모링가 뿌리추출물 처리에 의한 신장 섬유아세포의 mRNA 발현 저해

신장 섬유아세포에 TGF- $\beta$ 를 처리하여 섬유화를 유도한 뒤 모링가 뿌리추출물을 농도 별로 처리하여 섬유화 유도 인자인 PAI-1과 Type I collagen, fibronectin의 mRNA 발현에 대한 모링가 뿌리추출물의 영향을 확인하였다.

실험 결과, TGF- $\beta$ 처리에 의해 증가된 섬유화 유도 인자들 의 mRNA 발현이 모링가 뿌리추출물 처리에 의해 농도의존적 으로 감소하는 것을 확인하였으며, 특히 모링가 뿌리추출물에 의해 PAI- 1 의 발현이 가장 많이 감소함을 확인할 수 있었다 (Fig. 3). 따라서 이 결과로 모링가 뿌리추출물이 섬유화 유도 인자들 중 PAI-1의 mRNA 발현조절에 가장 영향이 있음을 예상할 수 있다.

모링가 뿌리추출물에 의한 TGF- $\beta 1$ 신호전달 기전의 인산 화 저해 및 발현 억제

PAI-1을 비롯한 섬유화 유도인자들은 TGF- $\beta$ 신호기전에 의해 활성화 되며[10], TGF- $\beta / S m a d$ 신호 기전은 MAPK kinase 신호전달 기전을 비롯한 PI3K/AKT 신호기전을 활성화 시킨다고 알려져 있다[41].

본 실험에서는, 모링가 뿌리추출물에 의한 섬유화 유도 인 자의 발현억제에 $\mathrm{T} \beta R$ 와 $\mathrm{MAPK}$ 의 인산화 정도에 영향이 있는 지를 확인 하였다. 신장 섬유아세포에 TGF- $\beta$ 를 처리하여 섬유 화를 유도시킨 뒤 모링가 뿌리 추출물을 농도 별로 처리하여 $\mathrm{T} \beta R \mathrm{RI}, \mathrm{Smad4}$, ERK의 발현과 인산화를 확인하였다. 실험결과 TGF- $\beta$ 에 의해 증가된 T $\beta R I I$ 의 인산화가 모링가 뿌리추출물 에 의해 감소되는 것으로 나타났으며, 그 하위의 신호기전인 $\mathrm{ERK}$ 와 Smad4의 인산화 또한 감소하였다. 그러나 모링가 뿌

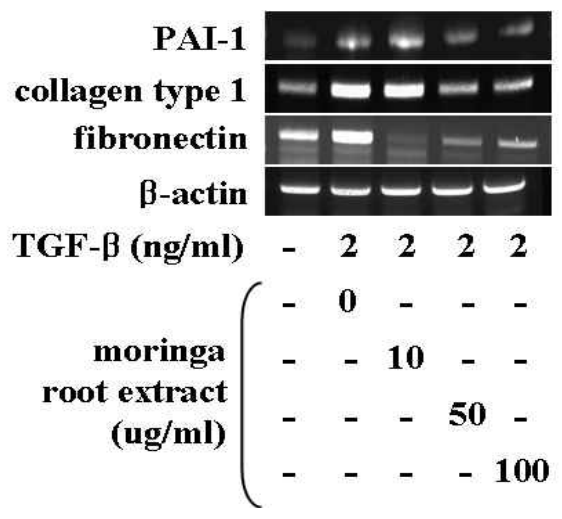

Fig. 3. Suppression of TGF- $\beta$-induced profibrotic factors by moringa root extract. Rat kidney fibroblast cells $\left(3 \times 10^{5} / 100 \mathrm{~mm}\right)$ were incubated with $2 \mathrm{ng} / \mathrm{ml}$ TGF- $\beta$ for $30 \mathrm{~min}$, followed by treatment with moringa root extract for $6 \mathrm{~h}$. mRNA expression was analyzed by RT-PCR. $\beta$-actin expression was included as an internal control. A representative of three independent experiments in shown.
리추출물을 농도 별로 처리한 경우, JNK와 p38 MAP kinase의 인산화에는 영향이 없었으며, PI3K와 그 하위의 AKT의 인산 화에도 영향이 없었다. 이 결과는 TGF- $\beta$ 가 ERK 신호기전을 통하여 PAI-1의 발현을 조절하지만 p38 MAP kinase를 통해 서는 조절되지 않는다는 연구결과와 일치함을 알 수 있다[7].

결과적으로 모링가 뿌리추출물에 의한 PAI-1과 Type I collagen, fibronectin의 발현은 ERK와 T $\beta R I I / S m a d 4$ 의 발현 및 인산화 저해를 통해 조절 되는 것으로 예상된다.

\section{고 찰}

섬유화는 사이토카인의 일종인 TGF- $\beta$ 에 의해 유도되며, TGF- $\beta$ 는 세포 외 기질의 축적 및 collagen 합성을 증가시켜 조직 경화를 유도한다[22]. 또한 TGF- $\beta$ 에 의해 활성화되는 섬 유화 유도 유전자인 PAI-1은 대식세포나 근섬유아 세포에서 발현이 증가하며 신장 섬유화 유도인자로 작용한다 $[8,26]$.

모링가는 씨, 뿌리, 잎, 꽃, 껍질 등이 화장품이나 의약품 등의 소재로 이용되고, 항염증 및 항암, 항산화제 등의 다양한 기능이 검증되고 있어 $[1,3,11,28]$, 본 연구에서는 TGF- $\beta$ 를 처 리한 신장섬유화 모델에 다양한 모링가 추출물을 처리하여 신장섬유화를 비롯한 섬유화 유도 유전자들에 대한 발현 및 조절기전을 확인하였다.

TGF- $\beta$ 를 처리한 신장섬유화 모델에 다양한 모링가 추출물

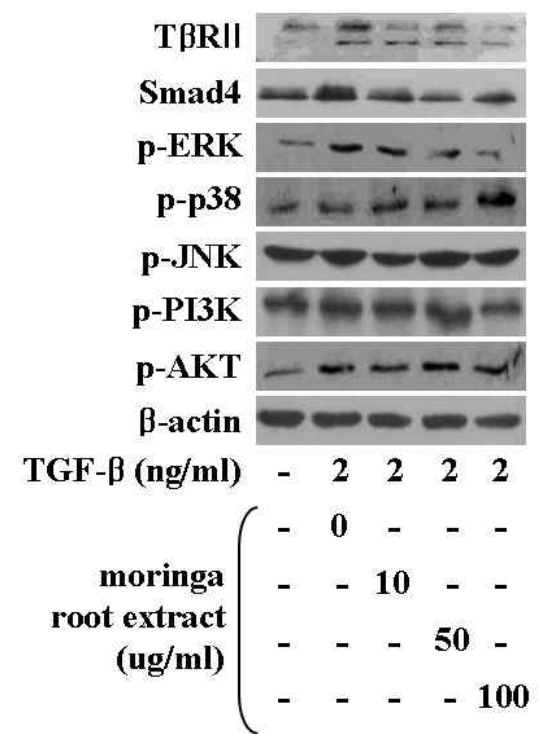

Fig. 4. Suppression of TßRII and its downstream signaling pathway by moringa root extract. Rat kidney fibroblast cells $\left(3 \times 10^{5} / 100 \mathrm{~mm}\right)$ were incubated with $2 \mathrm{ng} / \mathrm{ml}$ TGF- $\beta$ for $30 \mathrm{~min}$, followed by treatment with moringa root extract for $6 \mathrm{~h}$. Expression of cellular proteins were analyzed by western blot. $\beta$-actin expression was included as an internal control. A representative of three independent experiments in shown. 
들을 처리한 결과 PAI-1과 Type I collagen의 mRNA와 단백 질 발현이 감소함을 확인하였으며, 그 중 모링가 뿌리추출물 에 의해 가장 많이 감소되었다(Fig. 2). 본 결과를 재확인하기 위해 모링가 뿌리추출물을 농도 별로 처리한 경우에도 PAI-1, Type I collagen, fibronectin의 발현이 농도 의존적으로 감소 하였다(Fig. 3). 이 결과는 최근 확인된 모링가 씨 추출물이 간경화 완화를 통한 간 기능 보호 연구결과와 일치하며 모링 가 추출물들이 섬유화 억제 및 보호 효과가 있음을 확인할 수 있다[13].

또한 모링가 뿌리추출물에 의한 섬유화 유도 인자의 조절기 전을 규명하기 위해 TGF- $\beta$ 관련 신호 기전의 인산화 정도를 확인한 실험에서 모링가 뿌리추출물 처리 시 TRRII와 그 하위 의 신호기전인 ERK, Smad4의 인산화 및 발현이 저해되었으 며 JNK와 p38, PI3K/AKT의 인산화에는 영향이 없었다(Fig. 4). 최근 TGF- $\beta$ 가 처리된 신장 섬유아세포에서 Smad2 활성 저해는 세포 외 기질 분해를 억제하며, p38과 ERK1/2 활성에 의해 세포 외 기질의 축적이 증가된다는 연구결과가 보고된 바 있다[42]. 또한 TGF- $\beta$ 신호기전에서 Smad가 ERK1/2의 활 성에 필수적이지만, $\mathrm{p} 38$ 의 활성에는 비의존적이라고 알려져 있어[7,30], 모링가 뿌리추출물이 Smad4와 ERK에 의존적으로

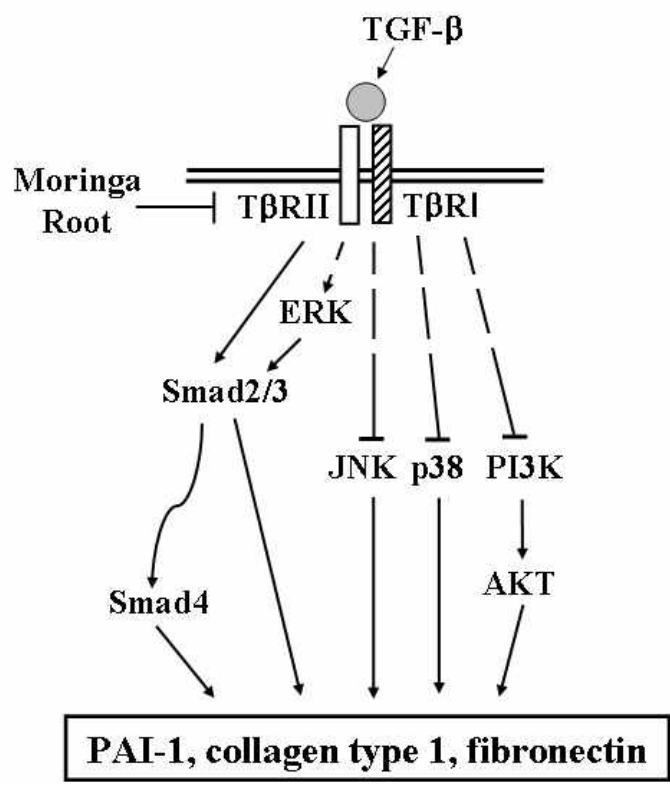

Fig. 5. Schematic model for suppression of profibrotic factor expression in rat kidney fibroblasts by moringa root extract. Moringa root extract selectively inhibited phosphorylation of TGF- $\beta$-induced T $\beta$ Rs, and downstream signaling pathway such as Smad4, and phospho-ERK, but not JNK, p38, and PI3K/AKT. As a result, TGF- $\beta$-promoted protein expression of Type I collagen, fibronectin, and PAI-1 was inhibited by moringa root extract. Moringa root extract blocks expression of profibrotic factors through the TßRII-Smad2/3-Smad4, and ERK. See text for detail.
작용함을 확인 할 수 있다. PI3K/AKT는 TGF- $\beta$-T $\beta R$ 를 통해 직접적으로 활성화 되거나 receptor tyrosine kinase의 transactivation을 통해 간접적으로 활성화되며[37], 폐 섬유화 모델에서 ROS에 의한 섬유화 유도 시 collagen 축적에 주요하 게 작용하는 작용기전으로 PI3K/AKT 기전은 TGF- $\beta$ 신호전 달 기전을 비롯한 다양한 인자들에 의해 활성화 된다[25]. 따라 서 Smad family와 MAPK, PI3K/AKT 신호전달 기전이 TGF$\beta-T \beta R$ 기전을 통한 신장섬유화 유도 및 발현 조절에 중요한 기전인 것으로 확인되며[7], 이러한 다양한 신호전달 기전 가 운데 모링가 뿌리추출물이 Smad와 ERK의 활성 저해를 통해 섬유화 조절에 주요하게 작용하는 것으로 생각된다(Fig. 5).

결론적으로 TGF- $\beta$ 로 유도된 신장섬유화 세포에서 모링가 뿌리추출물이 ERK와 TRRII/Smad4의 신호기전 조절을 통해 PAI-1과 Type I collagen, fibronectin의 발현을 저해하며, 이 결과로 모링가 뿌리추출물이 신장섬유화 저해 물질로의 개발 이 가능함을 예상할 수 있다. 또한 본 연구결과는 모링가 뿌리 추출물뿐만 아니라 다양한 모링가 추출물이 섬유화에 관한 연구에 사용될 수 있음을 제시한다.

\section{감사의 글}

이 논문은 2012년도 대구가톨릭대학교 교내연구비 지원에 의한 것임. 그리고 모링가는 (주)유림물산 이태용 이사에게 제 공받아 사용하였습니다.

\section{References}

1. Anwar, F., Latif, S., Ashraf, M. and Gilani, A. H. 2007. Moringa oleifera: a food plant with multiple medicinal uses. Phytother. Res. 21, 17-25.

2. Attisano, L, and Wrana, J. L. 2002. Signal transduction by the TGF-beta superfamily. Science 296, 1646-1647.

3. Bharali, R., Tabassum, J. and Azad, M. R. 2003. Chemomodulatory effect of Moringa oleifera, Lam, on hepatic carcinogen metabolising enzymes, antioxidant parameters and skin papillomagenesis in mice. Asian Pac. J. Cancer Prev. 4, 131-139.

4. Bhogal, R. K. and Bona, C. A. 2008. Regulatory effect of extracellular signal-regulated kinases (ERK) on type I collagen synthesis in human dermal fibroblasts stimulated by IL-4 and IL-13. Int. Rev. Immunol. 27, 472-496.

5. Border, W. A. and Noble, N. A. 1994. Transforming growth factor beta in tissue fibrosis. N. Engl. J. Med 331, 1286-1292.

6. Border, W. A. and Noble, N. A. 1997. TGF-beta in kidney fibrosis: a target for gene therapy. Kidney Int. 51, 1388-1396.

7. Cho, H. J., Kang, J. H., Kim, T., Park, K. K., Kim, C. H., Lee, I. S., Min, K. S., Magae, J., Nakajima, H., Bae, Y. S. and Chang, Y. C. 2009. Suppression of PAI-1 expression through inhibition of the EGFR-mediated signaling cascade in rat kidney fibroblast by ascofuranone. J. Cell. Biochem 107, 
335-344

8. Eddy, A. A. 2009. Serine proteases, inhibitors and receptors in renal fibrosis. Thromb. Haemost. 101, 656-664.

9. Eitzman, D. T. and Ginsburg, D. 1997. Of mice and men. The function of plasminogen activator inhibitors (PAIs) in vivo. Adv. Exp. Med Biol. 425, 131-141.

10. Gaedeke, J., Noble, N. A. and Border, W. A. 2004. Curcumin blocks multiple sites of the TGF-beta signaling cascade in renal cells. Kidney Int. 66, 112-120

11. Guevara, A. P., Vargas C., Sakurai, H., Fujiwara, Y., Hashimoto, K., Maoka, T., Kozuka, M., Ito Y., Tokuda, H. and Nishino, H. 1999. An antitumor promoter from Moringa oleifera Lam. Mutat. Res. 440, 181-188.

12. Guo, B., Inoki, K., Isono, M., Mori, H., Kanasaki, K., Sugimoto, T., Akiba, S., Sato, T., Yang, B., Kikkawa, R., Kashiwagi, A., Haneda, M. and Koya, D. 2005. MAPK/AP-1-dependent regulation of PAI-1 gene expression by TGF-beta in rat mesangial cells. Kidney Int. 68, 972-984

13. Hamza, A. A. Ameliorative effects of Moringa oleifera Lam seed extract on liver fibrosis in rats. Food Chem Toxicol. 48, 345-355.

14. Hayashi, H., Abdollah, S., Qiu, Y., Cai, J., Xu, Y. Y., Grinnell, B. W., Richardson, M. A., Topper, J. N., Gimbrone, M. A., Jr., Wrana, J. L. and Falb, D. 1997. The MAD-related protein Smad7 associates with the TGFbeta receptor and functions as an antagonist of TGFbeta signaling. Cell 89, 1165-1173.

15. Heldin, C. H., Miyazono, K. and ten Dijke, P. 1997. TGF-beta signalling from cell membrane to nucleus through SMAD proteins. Nature 390, 465-471.

16. Hocevar, B. A., Brown, T. L. and Howe, P. H. 1999. TGF-beta induces fibronectin synthesis through a c-Jun $\mathrm{N}$-terminal kinase-dependent, Smad4-independent pathway. EMBO J. 18, 1345-1356.

17. Hynes, R. 1985. Molecular biology of fibronectin. Annu. Rev. Cell Biol. 1, 67-90.

18. Imamura, T., Takase, M., Nishihara, A., Oeda, E., Hanai, J., Kawabata, M. and Miyazono, K. 1997. Smad6 inhibits signalling by the TGF-beta superfamily. Nature 389, 622-626.

19. Kohan, M., Muro, A. F., White, E. S. and Berkman, N. EDA-containing cellular fibronectin induces fibroblast differentiation through binding to alpha4beta7 integrin receptor and MAPK/Erk 1/2-dependent signaling. FASEB J. 24, 4503-4512.

20. Kornblihtt, A. R., Pesce, C. G., Alonso, C. R., Cramer, P., Srebrow, A., Werbajh, S. and Muro, A. F. 1996. The fibronectin gene as a model for splicing and transcription studies. FASEB J. 10, 248-257.

21. Kutz, S. M., Hordines, J., McKeown-Longo, P. J. and Higgins, P. J. 2001. TGF-beta1-induced PAI-1 gene expression requires MEK activity and cell-to-substrate adhesion. J. Cell. Sci. 114, 3905-3914.

22. Leask, A. and Abraham, D. J. 2004. TGF-beta signaling and the fibrotic response. FASEB J. 18, 816-827.

23. Lebrun, J. J., Takabe, K., Chen, Y. and Vale, W. 1999. Roles of pathway-specific and inhibitory Smads in activin receptor signaling. Mol. Endocrinol. 13, 15-23.

24. Liu, Y. 2006. Renal fibrosis: new insights into the pathogenesis and therapeutics. Kidney Int. 69, 213-217.

25. Lu, Y., Azad, N., Wang, L., Iyer, A. K., Castranova, V., Jiang, B. H. and Rojanasakul, Y. Phosphatidylinositol-3-kinase/akt regulates bleomycin-induced fibroblast proliferation and collagen production. Am J. Respir. Cell. Mol. Biol. 42, 432-441.

26. Lund, L. R., Riccio, A., Andreasen, P. A., Nielsen, L. S., Kristensen, P., Laiho, M., Saksela, O., Blasi, F. and Dano, K. 1987. Transforming growth factor-beta is a strong and fast acting positive regulator of the level of type- 1 plasminogen activator inhibitor mRNA in WI-38 human lung fibroblasts. $E M B O J .6,1281-1286$

27. Ma, F. Y., Tesch, G. H., Ozols, E., Xie, M., Schneider, M. D. and Nikolic-Paterson, D. J. TGF-\{beta\}1 activated kinase-1 (TAK1) regulates inflammation and fibrosis in the obstructed kidney. Am J. Physiol. Renal Physiol. 6, 1410-1421.

28. Mahajan, S. G. and Mehta, A. A. 2008. Effect of Moringa oleifera Lam. seed extract on ovalbumin-induced airway inflammation in guinea pigs. Inhal. Toxicol. 20, 897-909.

29. Meulders, Q., He, C. J., Adida, C., Peraldi, M. N., Schleuning, W. D., Sraer, J. D. and Rondeau, E. 1992. Tumor necrosis factor alpha increases antifibrinolytic activity of cultured human mesangial cells. Kidney Int. 42, 327-334.

30. Nakagawa, T., Lan, H. Y., Glushakova, O., Zhu, H. J., Kang, D. H., Schreiner, G. F., Bottinger, E. P., Johnson, R. J. and Sautin, Y. Y. 2005. Role of ERK1/2 and p38 mitogen-activated protein kinases in the regulation of thrombospondin-1 by TGF-beta1 in rat proximal tubular cells and mouse fibroblasts. J. Am Soc. Nephrol. 16, 899-904.

31. Nakao, A., Afrakhte, M., Moren, A., Nakayama, T., Christian, J. L., Heuchel, R., Itoh S., Kawabata, M., Heldin, N. E., Heldin, C. H. and ten Dijke, P. 1997. Identification of Smad7, a TGFbeta-inducible antagonist of TGF-beta signalling. Nature 389, 631-635.

32. Ponticos, M., Holmes, A. M., Shi-wen, X., Leoni, P., Khan, K., Rajkumar, V. S., Hoyles, R. K., Bou-Gharios, G., Black, C. M., Denton, C. P., Abraham, D. J., Leask, A. and Lindahl, G. E. 2009. Pivotal role of connective tissue growth factor in lung fibrosis: MAPK-dependent transcriptional activation of type I collagen. Arthritis Rheum 60, 2142-2155.

33. Rerolle, J. P., Hertig, A., Nguyen, G., Sraer, J. D. and Rondeau, E. P. 2000. Plasminogen activator inhibitor type 1 is a potential target in renal fibrogenesis. Kidney Int. 58, 1841-1850.

34. Samarakoon, R., Higgins, S. P., Higgins, C. E. and Higgins, P. J. 2008. TGF-beta1-induced plasminogen activator inhibitor-1 expression in vascular smooth muscle cells requires pp60(c-src)/EGFR(Y845) and Rho/ROCK signaling. J. Mol. Cell Cardiol. 44, 527-538.

35. Shi, Y., Hata, A., Lo, R. S., Massague, J. and Pavletich, N. P. 1997. A structural basis for mutational inactivation of the tumour suppressor Smad4. Nature 388, 87-93.

36. Siddhuraju, P. and Becker, K. 2003. Antioxidant properties of various solvent extracts of total phenolic constituents from three different agroclimatic origins of drumstick tree 
(Moringa oleifera Lam.) leaves. J. Agric. Food Chem 51, 2144-2155.

37. Souchelnytskyi, S., Nakayama, T., Nakao, A., Moren, A., Heldin, C. H., Christian, J. L. and Ten Dijke, P. 1998. Physical and functional interaction of murine and Xenopus Smad7 with bone morphogenetic protein receptors and transforming growth factor-beta receptors. J. Bid. Chem 273, 25364-25370.

38. Sreelatha, S., Jeyachitra, A. and Padma, P. R. Antiproliferation and Induction of Apoptosis by Moringa oleifera leaf extract on Human Cancer cells. Food Chem Toxicol. 6, 1270-1275.

39. Verrecchia, F. and Mauviel, A. 2004. TGF-beta and TNF-alpha: antagonistic cytokines controlling type I collagen gene expression. Cell Signal. 16, 873-880.

40. Wilson, H. M., Reid, F. J., Brown, P. A., Power, D. A., Haites, N. E. and Booth, N. A. 1993. Effect of transforming growth factor-beta 1 on plasminogen activators and plasminogen activator inhibitor-1 in renal glomerular cells. Exp. Nephrol. 1, 343-350.

41. Yue, J. and Mulder, K. M. 2000. Activation of the mitogen-activated protein kinase pathway by transforming growth factor-beta. Methods Mol. Biol. 142, 125-131.

42. Zhu, B., Wang, Y. J., Zhu, C. F., Lin, Y., Zhu, X. L., Wei, S., Lu, Y. and Cheng, X. X. Triptolide inhibits extracellular matrix protein synthesis by suppressing the Smad2 but not the MAPK pathway in TGF-beta1-stimulated NRK-49F cells. Nephrol. Dial. Transplant 25, 3180-3191.

\section{초록 : 모링가 뿌리 추출물에 대한 신장섬유화 억제 효과}

\section{박수현 ${ }^{1,2} \cdot$ 장영채, ${ }^{12}$ *}

( ${ }^{1}$ 대구가톨릭대학교 의용생체공학연구소, ${ }^{2}$ 대구가톨릭대학교 의과대학 의학과)

신장섬유화는 내 외부적인 요인들에 의해 발생하며, 그 요인들에 의해 염증이 생기고 지속적인 손상이 일어날 경우 신기능의 상실이 유발된다. 또한 신장섬유화는 세포 외 기질의 과다축적, TGF- $\beta$ 나, TNF-a, IL-1과 같은 사이 토카인에 의해 발생하며, TGF- $\beta$ 는 신장 섬유화의 과정과 Type I collagen과 fibronectin, PAI- 1 을 포함한 섬유화 관련 인자들의 발현 유도에 중요한 역할을 한다. 본 연구에서는 TGF- $\beta$ 를 처리한 신장섬유화 유도 모델에서 Moringa oleifera Lam 추출물에 대한 섬유화 관련 인자들의 영향을 확인하였다. 실험 결과 TGF- $\beta$ 로 유도된 신장 섬유화 세포에서 모링가 추출물이 fibronectin, Type I collagen과 PAI-1의 단백질 및 mRNA 발현을 저해하였으 며, 모링가 추출물 중 모링가 뿌리추출물이 가장 영향이 있는 것으로 확인 되었다. 모링가 뿌리추출물이 어떠한 기전을 통하여 섬유화 관련 인자들의 발현을 조절하는지 알아보기 위한 TGF- $\beta$ 로 유도된 TRRII 및 그 하위 기전 의 인산화 정도를 확인한 실험에서 모링가 뿌리추출물이 TGF- $\beta$ 로 유도된 TRRII과 그 하위기전의 Smad4, ERK의 인산화를 저해하였다. 그러나 TGF- $\beta$ 에 의해 유도된 JNK와 p38, PI3K/AKT의 인산화에는 영향이 없었다. 따라서 모링가 뿌리추출물이 TGF- $\beta$ 로 유도된 신장 섬유아세포에서 TRRII와 그 하위 기전인 Smad4, ERK를 통해서 Type I collagen 과 fibronectin, PAI-1의 발현을 조절하여 섬유화를 저해 한다는 것을 예상할 수 있다. 결론적으로 모링가 뿌리추출물이 섬유화 치료 및 완화에 좋은 물질이 될 수 있을 것으로 생각된다. 